\title{
Who Says Pornography Can't Be Art?
}

\author{
Hans Maes \\ *draft version, not for citation*
}

Many art historians, art critics, and philosophers of art have argued, or sometimes just assumed, that art and pornography are mutually exclusive. I aim to show that this popular view is without adequate support. ${ }^{1}$ I start by listing the different ways in which the distinction between art and pornography has been drawn in the past. While strong dichotomies of the sort I will discuss may help to illuminate the differences between certain prototypical instances of each, I argue that they do not serve to justify the claim that pornography and art are fundamentally incompatible. Next, I consider those definitions of pornography that make an a priori distinction between pornographic and artistic representations and I explain why such definitions should ultimately be rejected. Finally, after providing a critical assessment of one of the most recent and original arguments in the debate, I conclude by highlighting some of the practical implications of this philosophical discussion.

\section{A Black and White Distinction?}

In the existing literature one finds roughly four ways of marking the difference between artistic and pornographic representations. The line is drawn either on the basis of (1) representational content, (2) moral status, (3) artistic qualities, or (4) prescribed response.

(1) Representational content. Pornographic representations are sexually explicit and rich in anatomical detail. Art, by contrast, relies on suggestion and, instead of focusing on certain body parts, will try to capture the individuality, personality, and subjectivity of the represented person. This is one of the most common ways of distinguishing between the two one that figures prominently in accounts offered by Luc Bovens and Roger Scruton. The latter's standard example is Titian's Venus of Urbino. In this painting, as in all erotic art,

\footnotetext{
${ }^{1}$ This is a thoroughly revised and significantly extended version of a paper that appeared earlier in Philosophy Compass under the title: "Drawing the Line: Art versus Pornography".
} 
Scruton points out, it is not the sexual organs but the face, as 'window to the soul,' that provides the focus of attention (1986: 154, 2005: 11, 2009: 149). Luc Bovens takes this a step further and argues that it is precisely because artists refrain from overly graphic detail that they succeed in drawing the viewer into the first-person perspective of the depicted subject (1998: 215). Graphic representations, he thinks, only engage the spectator into a shameful gaze which will prevent her from developing such a phenomenal connection. Art, on the other hand, by retaining a suggestive character will exert a great pull on the imagination and invite the viewer to explore the mindset of the depicted person. Thus, art reveals in concealing, whereas pornography conceals in revealing (1998: 215).

A related and no less popular way of drawing the distinction is to say that pornography focuses on sex that is aggressive, emotionless, or alienated, whereas in art, and particularly in erotic art, love, passion, and equality between partners are of crucial importance (Webb 1975: 2; Ellis 2006: 30; Steinem 1995: 31; Mahon 2005: 15). In support of this view, authors often appeal to etymology. For while 'erotic art' ultimately derives from 'eros', the Greek word for love or passion, indicating an integrated sexuality based on mutual affection, the term 'pornography', whose etymological root is 'porne,' meaning prostitute, reflects a dehumanized, emotionless sexuality (see, for example, Webb 1975: 2, Steinem 1995: 31). In line with this, the novelists Kingsley Amis and E.J. Howard even went so far as to formally recommend, in their essay for the 1972 Longford Committee on Pornography, that the word 'love' be forbidden in the title of any work of hard-core pornography so as to avoid any misconceptions regarding its content (1972: 158). ${ }^{2}$

(2) Moral status. Delineating the distinctiveness of pornography, as opposed to (erotic) art, in terms of a particular content will not in and of itself establish that pornography is immoral. To begin with, even if one thinks that pornography always focuses on emotionless and impoverished forms of sexuality, one may insist that this makes pornography 'charientically flawed', i.e. coarse and vulgar, but not morally flawed (just like someone with vulgar manners or a coarseness of mind is not necessarily a morally corrupt person). ${ }^{3}$ Joel Feinberg $(1979,1985)$ makes this argument with regard to obscenity, but one could easily extend it to pornography. Furthermore, Theodore Gracyk (1987) has convincingly argued that

\footnotetext{
${ }^{2}$ Another famous novelist, D.H. Lawrence, once claimed that pornography is recognizable 'by the insult it offers, invariably, to sex and to the human spirit' (1929: 13). And he continues: 'Pornography is the attempt to insult sex, to do dirt on it. ... Ugly and cheap they make the human nudity, ugly and degraded they make the sexual act, trivial and cheap and nasty' (1929: 13).

${ }^{3}$ The term 'charientic' is derived from Peter Glassen's article '“Charientiec" Judgements' (Philosophy, 1958). A charientic judgement is an evaluative judgement, but one that concerns the non-moral qualities of an action, character, or representation. For instance, to judge someone as boorish and uncivilized (or, conversely, as refined and civilized) is to make a charientic judgment (see also Kieran 2002: 34).
} 
the morally objectionable character of a representation can never be just a matter of represented subject matter. For an artist can decide to depict rape or other aggressive forms of abuse in an attempt to precisely warn and protest against such degradation of women or men. That is why Helen Longino is careful to define pornography as : 'verbal or pictorial material which represents or describes sexual behavior that is degrading or abusive to one or more of the participants in such a way as to endorse the degradation' (1980: 43, my emphasis).

Longino is of course only one of the many authors who have tried to capture what is morally problematic about pornography. Since the aim of this essay is to investigate the artistic status of pornography I intend to put the intricacies of that debate aside here. However, I will introduce some of the more basic distinctions, because they can be, and have been, put to use in discussions on the distinction between art and pornography.

The most straightforward way to argue that pornography is morally objectionable (in a way that art is not) is to argue that it is harmful. The harm that pornography does may occur in the production phase, and take the form of coercion, brutality, violence, or rape. But even if no harm takes place in the making of pornography, and models are treated fairly and with respect, there can still be post-production harms. Some have argued that the pornographic materials themselves constitute harm because, as a form of hate speech, they silence and subordinate women (MacKinnon 1987, Langton 1993). Others have emphasised that exposure to pornographic material may cause harm (Eaton 2007). The latter claim is further refined by specifying the frequency of exposure (isolated / cumulative), the nature of the material (egalitarian / inegalitarian), the kind of harm inflicted (physical / attitudinal), and whom it is mainly inflicted on.

Pornography can be said to cause harm to a third party, in particular women, through the pernicious effect it has on the consumer, but some philosophers have also drawn attention to the harm that is supposedly caused to consumers themselves. Susan Dwyer (2008), for instance, argues that frequently watching pornography, much of which involves the humiliating and abusive treatment of others in a highly sexualized context, is like persistently engaging in bad thoughts about others. It is toxic and can erode ones moral character. Roger Scruton takes a slightly different line. Sexual desire in its fullest and most fulfilling form, he argues, 'is a desire for a person, someone who confronts me eye to eye and I to I' (2003). It is not a desire for sensations. Insofar as the consumption of pornography facilitates and promotes the brute pursuit of mere sensations, it does not contribute to an individual person's flourishing and rather diminishes that person's sense of self and moral integrity. In somewhat similar vein, it has been argued that devoting oneself sexually entirely or even primarily to 
pornography-aided masturbation, if a matter of choice, must be considered perverse, as it precludes the fully interpersonal sexual relations at the heart of an optimal experience of human sexuality (Levinson 2003).

'Exploitation' and 'objectification' are probably the terms that are used most often to describe what is wrong with pornography. Martha Nussbaum (1995), for instance, has written a seminal essay on different forms of objectification and how they apply to pornography, whereas artists like Nancy Spero have defined pornography as 'stuff that exploits women's bodies, and particularly in a harmful way' (Cembalest, 1989: 142). It might be thought, and indeed Spero and others have argued, that these ethical terms may serve to demarcate art from pornography - pornography being exploitative or objectifying in a way that art is not.

(3) Artistic quality. Those who are sceptical of the artistic potential of pornography will often put forward one or more of the following five reasons why pornography, by its very nature, will lack the kind of artistic quality that works of art are meant to possess. First, while art is necessarily complex and multi-layered, pornography is one-dimensional. That is because it has only one job to do. As a consequence, one will look in vain for the purposive and interpretive openness of art. Especially among art historians this appears a popular rational for separating art and pornography (see, for example, Webb 1975: 6, Mahon 2005: 14, Wallace, Kemp, and Bernstein 2007: 15). Second, works of art possess originality, whereas in pornography, as Nabokov once put it, 'action has to be limited to the copulation of clichés' (1995: 313). One is presented with the same kind of stock roles, sexual acts, flimsy narratives over and over again. This is not just a contingent feature of pornography. Pornographic films, novels, magazines are inherently formulaic. Because the pornographer's sole intent is sexual arousal, he has to insert as many sexually explicit scenes as possible, leaving no room for plot or character development. Moreover, the actual sum of possible sexual postures, gestures, and consummations seems drastically limited. In the words of George Steiner: 'the mathematics of sex stop somewhere around the region of soixante-neuf' (1975: 203) - which explains the inescapable monotony of pornographic representations (see also Amis and Howard 1972: 153).

A third and related complaint is that pornographic films, photographs, and stories are mass-produced commodities - products of what is aptly termed 'the porn industry'. A work of art, by contrast, is not an industrial product but a unique creation, carefully crafted and skilfully made. Fourth, art is concerned with beauty, while pornography is non-aesthetic and 'smutty.' In Civilization and its Discontents, Freud famously observed that 'the genitals themselves, the sight of which is always exciting, are hardly ever regarded as beautiful' 
(1961: 83). From this, it seems to follow that 'we only get beauty if we do not depict the site of sexual pleasure directly' (Danto 2003: 82). Another reason why pornography cannot be beautiful is offered by Roger Scruton: 'The pornographic image is like a magic wand that turns subjects into objects, people into things - and thereby disenchants them, destroying the source of their beauty' (2009: 163). To further illuminate this, Scruton appeals to the distinction between 'the nude' and 'the naked' made famous by Kenneth Clark (1956). The artistic nude constitutes, as the subtitle of Clark's book indicates, a 'Study in Ideal Form': the body is beautifully shaped and framed by the conventions of art. The people in pornographic images are not nude, but naked. They are deprived of clothes, and as such exposed or exposing themselves in an embarrassing way.

Fifth, art is imaginative, porn is pure fantasy. Both artists and pornographers deal in fictional worlds, but the imaginative creations of artists offer us a way of perceiving and understanding the reality we actually live in. Pornographers, by contrast, simply seek to refashion reality as the compliant object of our desires and fantasies (Scruton 2005: 13). Pornography depicts the world as its consumers would want it to be: a 'pornotopia' full of healthy, attractive men and women who seem to wish nothing more than to satisfy every possible sexual desire. ${ }^{4}$ It offers a realm of pure wish fulfilment, immune to constraints of plausibility, truth to life, or insight (Kieran 2001: 39). For Gordon Graham, art offers the exact opposite: it 'does not merely pander to taste but tries to educate it.' (2008: 160)

(4) Prescribed response. Pornography is also often characterised as an enemy of imaginative activity. George Steiner, for instance, accuses pornographers of doing our imagining for us and hence of showing no respect for the audience (1975: 210). While a poet (or painter) will invite the consciousness of the reader (or spectator) to collaborate with her own in what is basically a joint creative effort, the pornographer treats her audience as mere consumers whose imaginative means are set at nil. Indeed, the fact that we speak of consuming pornography and of appreciating art indicates that there is a fundamental difference in how we are meant to engage with both kinds of representation. The term 'consumer' suggests that there is less of an intellectually rewarding effort involved. It also fits with the common view of pornography as having nothing but instrumental value. Unlike a work of art, which is thought to be intrinsically valuable, a pornographic film or photograph is simply used to satisfy a need or gratify a desire; and when it has fulfilled that purpose, that is, when the product has been consumed, it is no longer of any interest.

\footnotetext{
${ }^{4}$ The term 'pornotopia' was first coined by Steven Marcus in his book The Other Victorians, published in 1964.
} 
Of course, in itself the distinction between consumption and appreciation is not going to be sufficient to draw a strict line between art and pornography. After all, consuming and appreciating something can go hand-in-hand. Think of a good wine or a nice meal. We can perfectly appreciate the intrinsic taste of a meal whilst knowing that it is also nourishing us. ${ }^{5}$ And a dish can be prepared with both aims in mind. So, more is needed if one wants to build a case for the incompatibility of art and pornography based on the kind of response that both invite or prescribe.

For instance, one could argue that art is to be contemplated in and for itself, whereas the lustful feelings evoked by pornography make contemplation impossible. St. Augustine already noted how the 'promptings of sensuality' typically block out all other functions, including most notably our rational faculties (Blackburn 2006: 52). But it is Schopenhauer who drives the point home with regard to the 'charming' in art. When paintings are designed to excite lustful feelings in the beholder, he states firmly, aesthetic contemplation is abolished and the purpose of art is defeated (1965: 207-8). ${ }^{6}$ In his testimony to the Longford committee on pornography Kenneth Clark voiced a similar complaint: 'To my mind art exists in the realm of contemplation ... the moment art becomes an incentive to action it loses its true character. That is my objection to painting with a communist programme, and it would also apply to pornography' (1972: 280). Scruton, too, has stressed that if a work of art 'arouses the viewer, then this is an aesthetic defect, a "fall" into another kind of interest than that which has beauty as its target' (2009: 160). ${ }^{7}$

In recent years, philosophers have proposed yet another way to spell out the difference between pornography and art in terms of the kind of regard for which they call. It is one that does not appeal to the notions of contemplation or imagination, but rather to a particular idea of what counts as an artistic or aesthetic interest. The latter, according to Christopher Bartel, 'requires one to take an interest in the formal qualities of the work' whereas a pornographic interest 'ignores these qualities in order to attend to the content of the work solely' (2010: 163). It is not hard to see how this distinction can be put to work in incompatibility arguments. The most influential of these is undoubtedly the one put forward by Jerrold

\footnotetext{
${ }^{5}$ One finds this observation in Shusterman 2007: 61.

${ }^{6}$ Shaftesbury also describes sexual feelings as 'a set of eager desires, wishes, and hopes, no way suitable ... to your rational and refined contemplation of beauty' (1999: 319).

${ }_{7}^{7}$ Before ascribing this firm stance exclusively to the arch-conservative worldview of Clark or Scruton, it is worth remembering that the very same view was put forward by the archetypal modernist, James Joyce, in his $A$ Portrait of the Artist as a Young Man. (For Joyce, 'proper art' is static, inducing what one could call 'aesthetic arrest', i.e. a rapt suspension of ordinary behaviour. Art that excites desire for an object he thinks is pornographic. It is a form of 'improper art' in that it is kinetic instead of static.)
} 
Levinson (2005). His argument, in a nutshell, is that the set of pornographic artworks is an empty set because art is centrally aimed at aesthetic experience, which essentially involves attention to form/vehicle/medium/manner, and pornography is centrally aimed at sexual arousal, which essentially excludes or wars against attention to form/vehicle/medium/manner.

\section{Shades of Grey}

How successful are these attempts to differentiate art and pornography? The answer to this question will depend on how ambitious exactly one takes these attempts to be. If the aim is simply to articulate some of the ways in which works of art can be different from the standard products of the porn industry, then there is really very little to find fault with. One need only compare, say, Rembrandt's Bathsheba at her Bath to Hustler Magazine to see almost every single point confirmed. In Hustler Magazine we find formulaic, smutty pictures that focus on sexual organs and serve only one purpose. The thoughts or personality of the women depicted are of no importance. They are presented only as objects of male fantasy. The contrast with Rembrandt's painting could not be greater. The artist depicts the moment where Bathsheba receives King David's letter, asking her to come to the palace. Bathsheba realizes what this entails - she will have to sleep with the King and betray her husband - and sadly foresees the deceit and suffering that will be caused by this (see Gaut 2007: 14-24 for a more detailed analysis of the work). All this is subtly visible in her facial expression, which is the central focus of the painting. Instead of taking up a voyeuristic, objectifying gaze (the way King David presumably saw her), Rembrandt's work expresses a deep sympathy with this woman and her precarious situation, and it invites the spectator to reflect on the similar fate of so many other women. It is a multi-layered, serenely beautiful, supremely original work of art.

But most of the authors discussed in section 1 aim to do more than just draw a contrast between such prototypical instances of art and pornography. They want to establish that art and pornography are mutually exclusive, so that if something is pornography it cannot be art and vice versa. But to make this claim convincing it obviously does not suffice to discuss examples that fit neatly into one of the two categories. Rather, one needs to show that the proposed distinctions are immune to counterexamples. That is, before drawing a definite and strict line between art and pornography based on the above dichotomies, we need to be convinced that the qualities ascribed to art are necessarily missing in pornography and, conversely, that there are no works of art that possess those features which supposedly 
disqualify pornography from the realm of art. That, I now want to argue, is a bridge too far. Counterexamples abound.

First, there are many works of pornography that actually possess the features exclusively ascribed to art in the list above. Examples that come to mind are films like All About Anna, made by Lars von Trier's production company Zentropa, Molly Kiely's graphic novel That Kind of Girl, or Dirty Diaries, a collection of Swedish movie shorts. All three belong to the rapidly growing subgenre of 'female friendly pornography' (or as the filmmakers of Dirty Diaries would have it, 'feminist pornography'). Far from being formulaic, they have original and imaginative scenarios, featuring life-like characters in realistic situations. They are carefully crafted and beauty is a primary concern. Much attention is paid to the personal experiences and the personality of the female leads, and 'feelings, passions, sensuality, intimacy, and the lead-up must be emphasised,' as it says in Zentropa's Puzzy Power Manifesto. Pornographic works of this sort not only avoid being vulgar or coarse, i.e. 'charientically flawed', but they also exhibit none of the moral flaws manifest in mainstream pornography (no exploitation, objectification, or denigration). What is more, in rejecting sexual repression, self-oppression, and hypocrisy, these works often have a positive, consciousness-raising force (McEllroy 1995; Willis 1995). By offering insights into female desire and sexuality they frequently serve an educational and emancipatory purpose (see Waugh 1995: 150 for similar arguments in favour of gay porn).

Second, there are many undisputed artworks that would fall on the 'wrong' side of the divide if the distinction were drawn along the lines suggested above. To begin with, and most obviously, some works of art focus on sex that is aggressive and alienated, rather than emphasising the love and equality between partners (Bernardo Bertolucci's Last Tango in Paris or Elfriede Jelinek's The Piano Teacher come to mind). Equally obvious is that not all works of art 'invite us into the subjectivity of another person' (Scruton 2009: 159). For instance, in Chrétien de Troyes's Lancelot, Francesco Petrarch's Sonnets to Laura, or the Roman de la Rose, the female is represented as an object of passion to be possessed, and her own autonomy and point of view are completely disregarded (Kieran 2001: 43). When Scruton praises the self-assured way in which the Venus of Urbino looks directly at the spectator, thereby signalling that she possesses her own body in a confident way instead of just being an object on display, he conveniently disregards other masterpieces by Titian, such as Venus and Adonis, Bacchanal of the Andrians and Danae and the Shower of Gold, where quite the opposite is true. In this regard, one could also point to more recent and more explicit works by Hans Bellmer or R. C. Hörsch where women and young girls are unmistakably 
objectified and remain without agency (Mey 2007: 22). The work of these artists also testifies to the fact not all art is, or is meant to be, beautiful.

Kenneth Clark claims that art loses its true character when it becomes an incentive to action, but clearly overlooks the fact that, besides communist posters, there are numerous religious paintings or politically inspired novels that call on people to change their lives and that we wouldn't want to deny the status of art. Similarly, Scruton believes that a work of art should never arouse the viewer or reader. But if one were to use this as a criterion to exclude pornography from the realm of art, one would also have to exclude erotic masterpieces such as D.H Lawrence's Lady Chatterly's Lover or Gustave Courbet's Sleep. Surely, that is too high a price to pay.

Then there is the claim that pornography cannot be art because it is formulaic. One can reply to this argument in a number of ways. The simplest is to point out that being formulaic does not preclude a work from realizing other artistic values or additional aspects of expressivity (Kieran 2001: 37). But one could also argue that being formulaic is not necessarily an artistically bad-making feature. Canterbury cathedral, for instance, has all the formulaic features of Gothic architecture, but is not a worse building because of that. Similarly, High Noon and The Searchers are formulaic Westerns which, I believe, cannot be faulted for being formulaic (note, furthermore, that both are products of an industry - the Hollywood industry). ${ }^{8}$

The same set of responses is available when facing criticism of the fantasy character of pornography. First, the fantastical nature of certain representations does not preclude them from realising other artistic values, or even from being 'true to life.' Klimt's nude studies, for example, are inherently fantastical in so far as they portray idealized, blank and even somnambulant young women, but as studies in sexual self-absorption they do not fail to be true to life (Kieran 2001: 40). Moreover, being fantastical is not necessarily an artistically bad-making feature. In the words of Susan Sontag, an account 'that faults a work for being rooted in "fantasy" rather than in the realistic rendering of how lifelike persons in familiar situations live with each other couldn't even handle such venerable conventions as the

\footnotetext{
${ }^{8}$ There is also reason to suspect that the formulaic, repetitive character of most pornographic films and photographs is in fact not an inherent feature of the genre, something that automatically comes with the subject matter, but rather a contingent feature and a consequence of the cheap production methods that are typically used.
} 
pastoral, which depicts relations between people that are certainly reductive, vapid, and unconvincing' (1994: 41).

Apart from counterexamples, there are also more general and fundamental objections against the above characterisation(s) of pornography. Take the claim that pornography is onedimensional. For Laura Kipnis, this idea is symptomatic of the prevalent desire among pornography commentators to vastly 'undercomplicate' the issue. Pornography offers a 'royal road to the cultural psyche' (2006: 118), she argues, and the experience of it is intensely complex and fraught with all the complications of personhood. As such, pornographic novels, photographs or films have many potential uses beyond the classic one-handed one. They can and often do serve as means of social criticism and cultural critique (Slade 2001: 293-294 also elaborates on the many different uses of pornography).

A similar argument was made by Susan Sontag in her famous defence of literary pornography. In this essay, with the telling title 'The Pornographic Imagination,' Sontag also rejected the idea that pornography is necessarily unimaginative. Novels like The Story of $O$ or Story of the Eye, she argues, are profound explorations of extreme states of human feeling and consciousness (1994: 42) and deserve to be ranked among the great achievements of the imagination. Linda Williams, author of Hard Core and editor of Porn Studies, has made similar claims about pornographic cinema, pointing out that one seriously underestimates the imagination if one thinks that it can only operate in the absence of, or only at the slightest suggestion of sexual representation (2008: 19).

It has already been noted how there are new forms of pornography, including pornography made by and for women, that do not seem morally objectionable. But even if one were to dispute this, and argue that there is something deeply wrong with any type of pornography, that in itself would still not be sufficient reason to exclude pornography entirely from realm or art - unless one adheres to an extreme form of moralism and thinks of moral value as the sole determinant of artistic status or artistic merit. But very few, if any, philosophers would defend such a view. Every plausible account of the relation between moral and artistic value, whether it is autonomism, ethicism, or contextualism, will acknowledge that works of art, even great works of art, can be morally flawed. Moreover, whatever (moral) objection one wants to bring forward against mainstream pornography, there is a good chance that it will also apply to at least some erotic art. Harm may be inflicted when art is being produced (Brown 2002 tells the harrowing story of Cellini and the Nymph of Fontainebleau) or may occur in post-production. In fact, a compelling case is made in this volume (by, respectively, Cooke and Eaton) that neither exploitation, nor objectification is 
unique to pornography and that both are present in many works of erotic art - a presence that is frequently unacknowledged precisely because critics tend to focus exclusively on pornography and too often consider art to be above (moral) criticism. In addition, some commentators have argued, pace Scruton, that it is 'the nude' and not 'the naked' which implies objectification and dehumanisation. According to John Berger, 'to be naked is to be oneself,' whereas a naked body has to be seen as an object on display for the spectator in order to become a 'nude' (Berger 1972: 54). ${ }^{9}$

Finally, I have said little about what is arguably the most influential account arguing for the distinctness of art and pornography, the one developed by Jerrold Levinson (2005), but that is only because other authors in this volume (in particular Davies and Kania) offer a convincing in-depth critique of his view (see also Maes 2009, 2011a, 2011b).

\section{Defining Pornography}

The dichotomies presented in section 1 can help to illuminate the differences between certain prototypical instances of pornography and art, but they will not serve to justify the claim that pornography and art are mutually exclusive. Of course, pornographic works might be said to have, by definition, no significant artistic or aesthetic aspect. George P. Elliott, for instance, defines pornography as 'the representation of directly or indirectly erotic acts with an intrusive vividness which offends decency without aesthetic justification' (1970: 74-75) and Fred Berger thinks it involves work 'which explicitly depicts sexual activity or arousal in a manner having little or no artistic or literary value' (1977: 184). By adding phrases like 'without aesthetic justification' or 'having no artistic value' these authors simply stipulate that nothing can succeed as both art and pornography. There lies the difference with authors like Scruton who argue, rather than stipulate, that pornographic works cannot possess beauty. For Scruton, the lack of aesthetic quality is a consequential feature, rather than a defining one - it follows from the fact that pornographic pictures are objectifying. For Berger and Elliot, the lack of artistic or aesthetic value is part of the concept of pornography.

\footnotetext{
${ }^{9}$ For a detailed and more nuanced discussion of objectification in relation to the artistic tradition of 'the nude', see Anne Eaton's chapter in this volume.
} 
Berger and Elliot explicitly endorse a normative definition of pornography, i.e. a definition that employs evaluative terms. ${ }^{10}$ Definitions of this kind inevitably bring to mind certain legal descriptions of obscenity such as the U.S. Supreme Court's notorious Miller test, set forth in Miller v. California (1973). This test proposed a three-pronged criterion for obscenity: $\mathrm{x}$ is obscene if (1) it is found appealing to the prurient interest by an average person applying contemporary community standards, (2) it depicts sexual conduct, specifically defined by the applicable state law, in a patently offensive way and (3) taken as a whole, it lacks serious literary, artistic, political or scientific value. The Miller test has proved problematic in many respects, one of its most evident flaws being the conflation of two ideas - the pornographic and the obscene. Martha Nussbaum (2004), Jon Huer (1987) and others have pointed out that the category of obscenity includes many non-sexual instances of transgression, excess, or taboo and is thus considerably broader than the category of pornography. Recent philosophical attempts to define the obscene have taken this insight on board - allowing for non-pornographic obscenities as well as pornography that is not obscene. Some of these accounts also do not exclude the possibility of obscene art (e.g. Kieran 2002).

Yet, what to think of definitions that exclude the possibility of pornographic art by reserving the term 'pornography' exclusively for representations that have no aesthetic or artistic value? In answering this question it may be helpful to look at a corresponding issue in moral debates on pornography, where some authors have proposed to use the term 'pornography' only for those sexually explicit representations that are considered morally objectionable. One obvious example of such a normative characterisation would be Susan Brownmiller who characterises pornography as 'the undiluted essence of anti-female propaganda' (1975: 394).

Susan Dwyer (2008) has argued that normative characterisations of this kind are ideally suited to motivate people into doing (or not doing) certain things. In her terminology, a normative characterisation is ideal to perform the 'strategic function' of language. For instance, if you wish to convince the local authorities to ban pornography from newsstands, then a normative characterisation will prove a powerful tool. It's hard to imagine that local officials would not be motivated to remove instances of undiluted anti-female propaganda from public view... However, if one wants to use words simply to pick out things in the world for further investigation, that is, to perform the 'identification function' of language, then, she

\footnotetext{
10 Even those who subscribe to a normative definition of pornography may believe that there is some pornography that qualifies as art. But what they are forced to reject is that something can be a successful instance of both art and pornography. If there is some pornography that qualifies as art, it must be bad art.
} 
argues, a descriptive, value-neutral characterisation is needed. So, a philosophical enquiry into the moral status of pornography should start with a value-neutral description of what pornography is. Only once we know what it is, are we in a position to evaluate its moral status. Similarly, one could say that a philosophical enquiry into the artistic status (or aesthetic dimension) of pornography should start with a value-neutral characterisation of pornography. Of course, this presupposes that pornography is a non-evaluative concept that allows for a purely descriptive definition (unlike, say, the concept of 'kitsch'). But this is a reasonable presupposition. Indeed, the whole debate about whether or not something can succeed as both pornography and art rests on that assumption and would simply be a nonstarter with a normative definition like the ones proposed by Elliott or Berger.

That being said, an adequate value-neutral definition of pornography that captures as much of the extension as possible of what we ordinarily think counts as pornography is not easy to find. Michael Rea (2001), one of the very few authors who has devoted an essay to the issue of defining pornography, proposes the following:

$x$ is pornography if and only if it is reasonable to believe that $x$ will be used (or treated) as pornography by most of the audience for which it was produced.

He then goes on to specify what it means for someone, $\mathrm{S}$, to use something, $\mathrm{x}$, as pornography. He lists four conditions (2001: 120):

(i) $x$ is a token of some sort of communicative material;

(ii) $\mathrm{S}$ desires to be sexually aroused or gratified by the communicative content of $\mathrm{x}$;

(iii) if $\mathrm{S}$ believes that the communicative content of $\mathrm{x}$ is intended to foster intimacy between $\mathrm{S}$ and the subject(s) of $\mathrm{x}$, that belief is not among $\mathrm{S}$ 's reasons for attending to X's content;

(iv) if S's desire to be sexually aroused or gratified by the communicative content of $\mathrm{x}$ were no longer among S's reasons for attending to that content, $\mathrm{S}$ would have at most a weak desire to attend to x's content.

One can have doubts about the third requirement - the 'no intimacy' requirement. It is meant to rule out such things as the pictures or videos that a person might make for the private viewing pleasure of his or her spouse. Yet, one may wonder whether these should in fact be ruled out, given that there are plenty of internet guides for couples who want to experiment in 
this way, with titles ("Make your own porn film" / "Star in your own porn movie") that suggest that such home videos are commonly regarded as pornography. But this is just a minor quibble. It is the fourth condition that poses a real problem. What it in fact does is exclude from the realm of pornography any pornographic material with enough educational or curiosity value to keep an audience fascinated beyond the moment of sexual release. More importantly, it also seems an oblique way of establishing that something will not count as pornography if it has sufficient artistic value to capture and sustain the audience's attention independent of any sexual interest. In other words, it looks as if, for Rea, too, the lack of artistic or aesthetic value is part of the concept of pornography. Hence, on close inspection, his apparently value-neutral definition turns out to be very much motivated by a normative agenda.

When Bernard Williams chaired the Committee on Obscenity and Film Censorship in the 1970s he proposed the following definition: 'a pornographic representation is one that combines two features: it has a certain function or intention, to arouse its audience sexually, and also has a certain content, explicit representations of sexual material (organs, postures, activity, etc).' (8.2) The first condition is needed because there are sexually explicit representations that we would not ordinarily label as pornography, e.g. didactic illustrations in medical handbooks or documentaries of sex workers. The second condition is added mainly to distinguish pornographic representations from those that are 'merely' erotic.

I think this comes close to how most of us understand the term. Still, as it stands, the definition seems too inclusive. Suppose a film or novel contains both an erotic but nonexplicit love scene and an episode in a gynaecologist's office that is explicit, but not meant to be arousing. That film or novel would combine the two features listed above, but it would not count as pornography. So, the simple conjunction of explicitness and the intention to arouse is not enough. The two aspects must in some way be interrelated. Without formalising things too much one could say that a pornographic representation is (1) made with the intention to arouse its audience sexually, (2) by prescribing attention to its sexually explicit representational content. ${ }^{11}$

The first condition, though absent in the definitions offered by Elliot and Berger is fairly uncontested nowadays. The second condition is more controversial. Levinson, for

\footnotetext{
${ }^{11}$ Linda Williams offers a similar definition of pornography: "the visual (and sometimes aural) representation of living, moving bodies engaged in explicit, usually unfaked, sexual acts with a primary intent of arousing viewers' (1989: 30). According to Matthew Kieran, pornography 'seeks, via the explicit representation of sexual behaviour and attributes, to elicit sexual arousal or desire.' (2001: 32) See also the definition proposed by David Davies in this volume.
} 
example, argues that some erotic paintings and photographs are just as explicit or even more explicit than pornographic pictures. He therefore proposes a different way of distinguishing between the two. According to Levinson, pornographic representations are essentially aimed at sexual arousal, whereas erotic images are aimed at sexual stimulation. The former he describes as 'the physiological state that is prelude and prerequisite to sexual release' whereas the latter should be understood as 'the inducing of sexual thoughts, feelings, imaginings, or desires' (2005: 229). However, given that sexual feelings, thoughts and desires are typically accompanied by and conducive to sexual arousal, it is hard to see how this distinction is more plausible and useful than the one it seeks to replace.

Other opponents of that second condition appeal to the fact that magazines directed at bondage fetishists (or shoe fetishists) need not be explicit to be arousing, which seems to indicate that sexual explicitness is not a necessary condition for something to count as pornography. ${ }^{12}$ But this, too, I think, is hardly a knock-down argument. For why not call nonexplicit bondage pictures 'erotic', just like we call the suggestive, but non-explicit pictures of models in lingerie 'erotic' but not 'pornographic'? Surely, the fact that a model is wearing leather instead of lace cannot make all that much difference?

It is striking that those who insist that the category of pornography is purely one of function, and who reject an intrinsic feature like sexual explicitness as a suitable criterion of demarcation, often have no trouble in accepting another non-functional feature as part of the definition of pornography. Almost everyone seems to agree that pornography is a subcategory of the class of representations and that only a representation (or, as Michael Rea would have it, a token of some communicative material with communicative content) can come to qualify as pornography. It seems right to insist on this. ${ }^{13}$ After all, there is no such thing as abstract pornography. And few people would be inclined to use the label 'pornography' for erotic massages, or Viagra, or Woody Allen's Orgasmatron. ${ }^{14}$ But if the category of pornography really were to be purely one of function, then why draw the line at representations and rule out these other things? If one intrinsic feature (being a representation) is accepted as part of the definition, then why such strong resistance against that other intrinsic feature (being sexually explicit)? Opponents will point out that the 'connection between sexual arousal and sexual explicitness is purely contingent' (Mag Uidhir 2009: 196). But the connection between

\footnotetext{
${ }^{12}$ One finds this argument in both Rea (2001) and Mag Uidhir (2009).

${ }^{13}$ The term 'pornography' is partly derived from the Greek word 'graphein', meaning 'writing' or 'representing'. Incidentally, this is one of the notable differences between the erotic and the pornographic. The erotic is not limited to the class of representations.

${ }^{14}$ A (fictional) electromechanical device designed to induce orgasms (from the film Sleeper).
} 
sexual arousal and representational character is even more contingent. That doesn't change the fact that the representational character of pornography is not just a contingent feature. It seems to me that the same is true for sexual explicitness.

For our purposes, whether or not one is willing to adopt the 'explicitness' condition is not such a pressing matter because in recent discussions on the artistic potential of pornography nothing really turns on that issue. It is not the fact that pornography is sexually explicit, but rather the fact that, and the way in which, it aims to bring about sexual arousal that is considered to be the big stumbling block for any artistic redemption of pornography. In the next section I will discuss the most recent argument put forward by a philosopher who believes not just that there are important differences between typical examples of pornography and art, but that art and pornography are fundamentally incompatible.

\section{Pornography and Manner Specificity}

In 'Why Pornography Can't Be Art' (2009: 194) Christy Mag Uidhir defends his uncompromising view as follows:

(1) If something is pornography, then that something has the purpose of sexual arousal (of some audience).

(2) If something is pornography, then that something has the purpose of sexual arousal and that purpose is manner inspecific.

(3) If something is art, then if that something has a purpose, then that purpose is manner specific.

(4) If something is art, then if that something has the purpose of sexual arousal, then that purpose is manner specific.

(5) A purpose cannot be both manner specific and manner inspecific.

(6) Therefore, if something is pornography, then it is not art.

The somewhat idiosyncratic notion of a manner specific purpose is defined as a purpose that is essentially constituted both by an action (or state of affairs) and a manner, such that the purpose is to perform that action (or bring about that state of affairs) in that particular manner (2009: 194). For a purpose to be manner inspecific, by contrast, is simply for it not to be 
manner specific. In other words, if a purpose is manner inspecific, then failure to bring about the state of affairs in the prescribed manner does not constitute failure to satisfy the purpose.

Mag Uidhir's account has a number of distinct virtues - originality not being the least of them. What he presents is an entirely new argument that does not seem to fit in any of the categories listed in section 1. Furthermore, his account is not based on any robust theories of art or pornography. Mag Uidhir only invokes a limited set of necessary conditions. Given how difficult it has proven in the past to define either what art or what pornography is, this certainly seems a commendable strategy. While, for instance, Levinson's argument is bogged down by the controversial claim that (erotic) art's main purpose is to create an aesthetic experience and draw attention to its own formal features, Mag Uidhir's argument does not rely on any such substantial claim. He does not even claim that art has or should have a purpose. Mag Uidhir only asks us to accept that if a work of art has a purpose, including perhaps the purpose of sexual arousal, then that purpose must be manner specific. This brings us to another added bonus of Mag Uidhir's approach. Mag Uidhir leaves room for the idea that art, like pornography, can aim to bring about sexual arousal. Scruton and Clarke, among many others, have to deny this since their whole argument rests on the thought that sexual arousal and aesthetic contemplation are incompatible. Still, regarding the central issue, he aligns himself squarely with those who reject the possibility of pornographic art. He, too, thinks that artists or pornographers attempting to produce something that is both art and pornography, in fact attempt the impossible. But is his case ultimately a compelling one?

Mag Uidhir aims to demonstrate that art and pornography are radically separate categories by showing that the success conditions for these categories are fundamentally different. Premise (4) specifies that, for something to count as a sexually arousing work of art, i.e. a work of art that fulfils its purpose of bringing about sexual arousal, it needs to bring about sexual arousal in the prescribed way. Premise (2), by contrast, states that for something to count as a successful work of pornography, i.e. a work of pornography that fulfils its purpose, it needs to bring about sexual arousal, period. In Mag Uidhir's own words, the 'sexual arousal of the audience simpliciter matters ... This is precisely what it means to be manner inspecific' (2009: 197). If these premises are accepted as true, then what has been established is that there is an important difference between the category of art and the category of pornography.

What has not been shown, however, is that these categories are mutually exclusive. In order to show that something cannot legitimately fall under both categories, it is simply not enough to argue that their respective success conditions are different. One needs to show that 
it is impossible for a particular object to fulfil both success conditions. And Mag Uidhir's argument does not do that. Not only is it perfectly possible for a particular work to satisfy both success conditions, but satisfying the success conditions for sexually arousing art even seems to entail satisfying the stated success conditions for pornography. For suppose that a novel, a photograph or a film brings about sexual arousal in the prescribed way (and we can take this to mean whatever Mag Uidhir wants it to mean). Then it will have fulfilled the success condition for sexually arousing art ('for something to count as a sexually arousing work of art, it needs to bring about sexual arousal in the prescribed way') as well as the success condition for pornography ('for something to count as a successful work of pornography it needs to bring about sexual arousal, period').

Still, Mag Uidhir may retort that if a novel, photograph, or film brings about sexual arousal in the prescribed way, then the particular manner in which it does that is either essential or not. It cannot be both. And, he might argue, whether we are dealing with pornography or art will depend on which of the two is the case. In other words, when one is confronted with a work that is sexually arousing in the prescribed way, rather than just accept that the work fulfils the success conditions for both art and pornography, one should engage in counterfactual reasoning and ask the following question: If this work had brought about sexual arousal, but not in the prescribed way, would it be considered a failure? If the answer is 'no', we are dealing with a work of pornography. If the answer is 'yes', it is a work of art. There is no middle ground.

However, this manoeuvre will not save Mag Uidhir's argument. For why could the answer to the counterfactual question not be 'yes' and 'no'? Yes, it would have failed as a work of art had it not brought about sexual arousal in the prescribed way. But it would not have failed as a work of pornography. And given that, factually, it does bring about sexual arousal in the prescribed way, it satisfies the success conditions of both art and pornography. A comparison that was originally suggested by Mag Uidhir himself may be helpful here. ${ }^{15}$ Suppose two people are playing a ball game but we are not quite sure which game they are playing. We know that the winning condition of Game 1 is this:

(g1) A person wins the game if and only if that person throws the ball through all of the designated hoops in the order that person declared prior to the aforementioned throw.

\footnotetext{
${ }^{15}$ Mag Uidhir suggested this in a personal communication to the author.
} 
And the winning condition of Game 2 is:

(g2) A person wins the game if and only if that person throws the ball through all of the designated hoops.

Now suppose that we see one of the players, let's call her A, throw the ball through all of the designated hoops in the order that she declared prior to her throw. She is the winner, that much is clear. But which game did she win?

Here is Mag Uidhir's take on this problem. It is true that satisfying the condition in (g1) entails that the state of affairs in condition (g2) obtains. It does not follow from this, however, that satisfying winning condition (g1) entails also satisfying winning condition (g2). Because it cannot be the case that (g1) and (g2) are both winning conditions for one and the same game of ball; for if one of the above stated winning conditions is true, the other must be false. So, the crucial question is a counterfactual one: had A thrown the ball through all the hoops, but not in the right order, would she still have won the game? If the answer is 'yes', then they were playing Game 2. If the answer is 'no', they were playing Game 1.

But, one might ask, what if they were playing both games at the same time? The fatal flaw in Mag Uidhir's argument is that he does not consider this possibility. Why could player A not try to win both games with one throw? The fact that the winning conditions of both games are incompatible, in the sense that one and the same game cannot have both winning conditions, does not make such an attempt incoherent or impossible. ${ }^{16}$ If we return to the case of art and pornography, we see that the same holds true there. Granted, a purpose cannot be both manner specific and manner inspecific. But why could one not try to create a work that satisfies two purposes, one of which is manner specific, one of which is not? There seems to be nothing illogical about that. Why would an artist, after finishing a novel or film, not be able to say: 'As a pornographer, I'll be happy if people are sexually aroused by my work, but as an artist, I want to achieve more; I want to arouse my audience in such a way that they gain new insight into their own sexuality and desires.' If such a statement and that sort of ambition is intelligible and coherent, we cannot but conclude that Mag Uidhir's argument fails. ${ }^{17}$

\footnotetext{
${ }^{16}$ Only if satisfying success condition (g1) were to exclude satisfying success condition (g2) would it be incoherent to try to win both games with one attempt.

${ }^{17}$ There is a particular reading of the third premise of Mag Uidhir's argument that would nullify the objections I have raised. Premise 3, you will recall, states that if something is art, and if that something has a purpose, then that purpose is manner specific. Presumably, what Mag Uidhir wants to say here is that a work of art's artistic
} 
In a sense, this outcome is not just reassuring for the advocates of pornographic art. If Mag Uidhir's argument had been successful it would have been very easy to construct similar arguments showing how nothing can be both religious iconography and art, or propaganda and art, or advertising and art - to name just a few other practices with so-called mannerinspecific purposes. The fact that Mag Uidhir's approach, applied consistently, would force us to exclude Toulouse-Lautrec's advertising posters or Eisenstein's propagandistic films from the realm of art, I consider to be just another consideration against the position that he defends. $^{18}$

\section{Practical Implications}

To some, the whole debate may seem like the philosophical equivalent of shadowboxing - a mere fight over words, without any real world impact. But nothing could be further from the truth. Yes, the "art or porn?" question is at heart a conceptual issue, but one with considerable practical implications. The fact that this is one of the very few philosophical questions that regularly appears as a newspaper headline is ample evidence for this. It can make a huge difference whether something is labelled as one or the other, and journalists know this all-toowell.

Being awarded the status of art brings with it social prestige and institutional recognition and makes a painting, novel or film into a legitimate object of interest for the mainstream press and academia. In contrast, if a work is branded as pornography it will usually have to forego any serious critical or academic attention. Worse still, the work may become the victim of censorship and be banned from museums, book stores, movie theatres even to the point of being confiscated and destroyed.

purposes - those that are constitutive of it as a work of art - are necessarily manner specific. Such a claim, though not uncontroversial, would at least not be wildly implausible. However, one could read the third premise literally as saying that any purpose a work of art may have will be a manner specific one. Interpreted that way, a work of art can never have a manner inspecific purpose, which would undermine the objections raised above. If works of art only ever have manner specific purposes, and if one defines pornography as necessarily having a manner inspecific purpose, then nothing can be both art and pornography. But, of course, interpreted in this overly strict way the third premise is plainly false. Works of art can and do have all sorts of purposes - practical purposes, economic purposes, didactic or pedagogical purposes, political, social, or moral purposes, etc. - and many of these will not be manner specific. Denying this would be like denying that one can play two games at the same time.

${ }^{18}$ Another example would be Spike Jonze, who was nominated by the Directors' Guild Of America in 2006 for his "Outstanding Achievement in Commercials", notably for his "Lamp" ad for IKEA and "Hello Tomorrow" ad for Adidas. One commentator describes the latter as follows: "Beautifully constructed and wonderfully scored it's a surprisingly affecting advert ... A piece of art that just so happens to be affiliated with and paid for by a multinational sports clothing corporation." (Plumb 2011) 
Over the course of centuries, that fate has befallen many works of pornography, including works made by established and admired artists. J.M.W. Turner's pornographic drawings, for example, were burnt by John Ruskin, ${ }^{19}$ while Richard Burton's daring translation of The Scented Garden was destroyed by his wife after his death. Giulio Romano, who was one of Raphael's most gifted pupils and helped to complete Raphael's Transfiguration and Coronation of the Virgin, made a series of 16 drawings of couples in various sexual positions that were later made into engravings by Marcantonio Raimondi. None of the original engravings of I modi (The positions) have survived due to censorship and persecution (Talvacchia 1999). ${ }^{20}$ And while several of the sexually explicit frescoes of Pompeii and Herculaneum were cut from the walls and kept in the (in)famous Pornographic Cabinet in the Naples Archaelogical Museum, many others were simply destroyed on the spot (Clarke 2003).

For works of this kind - works which are pornographic in content and aim but which also have undeniable artistic merit or credentials, the threat of marginalisation and criminalisation has persisted throughout the $20^{\text {th }}$ and $21^{\text {st }}$ century. Egon Schiele received a prison sentence in 1912 on charges that his work was pornographic and a local judge actually burnt one of his drawings in the courtroom. When The Story of $O$ (Pauline Réage / Anne Desclos) was first published in 1954 obscenity charges were brought against the publisher and even though the attempt to ban the novel proved unsuccessful, a publicity ban was imposed for several years. In 1989, following strong conservative opposition to controversial funding made by the National Endowment for the Arts, the Corcoran Gallery of Art in Washington DC cancelled the exhibition, Robert Mapplethorpe: The Perfect Moment, which contained sexually explicit homo-erotic images. More recently, Alan Moore's pornographic masterpiece, Lost Girls (2006), which he co-created with his wife, Melinda Gebbie, received none of the mainstream attention that his other work has received (his celebrated graphic novels From Hell, Watchmen, V for Vendetta, The League of Extraordinary Gentlemen have all been turned into films, but, unsurprisingly, no one has offered to buy the film rights for Lost Girls).

\footnotetext{
${ }^{19}$ Quite a number of these drawings have actually survived which has lead some scholars to suspect that Ruskin may have invented the story to deflect the interest of the authorities after the Obscene Publications Act of 1857.

${ }^{20}$ Arthur Danto points out that Raphael 'was not above doing a bit of pornography himself now and then. His notorious 1516 frescoes of the history of Venus, commissioned for cardinal Bibbiena's bathroom in the Vatican, were whitewashed over in the nineteenth century as inconsistent with what was felt to be spiritually fitting for the artist of the Acts of Apostles' (2005: 123).
} 
What is interesting is that those who have taken up the defence of these and similar works, and have lobbied for their protection or rehabilitation, have almost always opted for the same strategy, namely to reject the label of pornography as forcefully as possible and make the case that such works qualify as 'erotic art' instead. This strategy is clearly rooted in the idea that art and pornography must be mutually exclusive. It is, however, not the only available or viable route to take. There is an alternative. One could see the choice between art and pornography for what I think it really is - a false dilemma - and acknowledge that certain works of art can also qualify as pornography and vice versa. The latter approach has almost never been adopted in the past (it is quite revealing, for instance, that there is not a single art historical book that carries the phrase 'pornographic art' in its title). This needs to change. For, as I have tried to show in this chapter, there are really no good theoretical reasons to believe that art and pornography are incompatible. Moreover, there are some compelling practical reasons to give up the strict dichotomy between art and pornography and start using the label 'pornographic art' instead of always, coyly and euphemistically, reverting to the category of erotic art. To substantiate this last claim, I will refer to the practice of art criticism and to past, current, and future art-making practices.

When artists such as Pauline Réage, Egon Schiele, Robert Mapplethorpe, created their sexually explicit and arousing works they were not only inspired and influenced by the long and respectable tradition of erotic art, but also by the pornography that was available in their day and which they often tried to imitate or emulate. Hence, a full and accurate appreciation of these works - one that can account for all the allusions, references, and borrowed imagery - is impossible if one ignores their pornographic pedigree. Furthermore, even if these works were to contain no direct references to particular pornographic predecessors, it would still be advisable, from an art critical point of view, to compare them to other works of pornography because this will allow the critic to evaluate how innovative and effective these works really are. As Alan Moore has put it bluntly: 'Pornography is very much like adolescent poetry: there's a great deal of it about because it is a very easy thing to do, and much of it is absolutely fucking dreadful because it is very hard to do well.' (2008: 9) It is precisely by drawing the comparison with other pornographic works, by investigating which genre markers are incorporated or subverted, and by asking to what extent is the pornographic aim of arousal through explicitness is achieved, that one will be able to assess the success of these works.

In his influential essay, 'Categories of Art' (1970), Kendall Walton argues convincingly that the correct aesthetic evaluation of a work depends crucially on perceiving it 
in the correct category. Whether a work is correctly perceived in a particular category, he argues, is partly determined by (a) the fact that the artist who made the work intended it to be perceived in that category; and (b) the fact that the category is well-established in the society in which the work was produced. ${ }^{21}$ Given that the art critic is supposedly 'an expert concerning the categories of art' (Carroll 2009: 97) it is both surprising and regrettable that, when it comes to pornographic artworks, art critics as well as art historians are so reluctant to perceive them in the category of pornography for which these works were intended and that was well-established at the time of creation.

Take the pornographic drawings and paintings by Egon Schiele. In art historical studies these are typically discussed within the broader context of the artist's oeuvre. Sometimes the chosen comparison class will include contemporary or classic works of erotic art. But they are rarely, if ever, compared to other works of pornography of the time, and their effectiveness in arousing the spectator is never a topic of discussion. ${ }^{22}$ The same is true for pornographic literature. Critical discussions of Louis Paul Boon's “Mieke Maaike's Obscene Jeugd" (1971), Alain Robbe-Grillet "Un Roman Sentimental” (2009), Nicholson Baker's "House of Holes" (2011) will refer to other novels by the same author or to some classics of erotic literature, but rarely does one find a meaningful or extensive comparison with examples of pulp pornography that were a direct source of inspiration for these authors. Take any other genre, from whatever art form, and such an omission would be unheard of (comparable to reviewing a masterpiece of science-fiction or horror fiction - think of Kubrick's 2001 or The Shining - without mentioning any other film within that genre, or any of the genre's standards and requirements).

In 'Categories of Art' Walton also famously makes a distinction between standard and contra-standard properties. Features are standard relative to a certain category if they are among those in virtue of which works in a certain category belong to that category (think of the flatness of a painting), whereas contra-standard features tend to disqualify a work from a category in which we nevertheless perceive it (think of a three-dimensional object glued to the surface of a painting). How a work affects us aesthetically, Walton observes, depends on which of its features we see as standard and which as contra-standard. Standard features will

\footnotetext{
${ }^{21}$ Walton does mention other criteria, including: the fact that a work is better, or more interesting or more pleasing aesthetically when perceived in that category. But this criterion has proved controversial and is rejected (rightly so, I think) by other philosophers such as Noël Carroll.

${ }^{22}$ Schiele's work is discussed in Alyce Mahon's Eroticism \& Art and while the book contains many images and discussions of works which are non-erotic and non-explicit (including: Yolanda Lopez, Portrait of the Artist as the Virgin of Guadalupe, 1978; David Wojnarowitcz, The Death of American Spirituality, 1987; and Tracey Emin's Bed, 1998-9) she remains silent on the genre of pornography and how it may have influenced artists like Schiele.
} 
typically not seem striking or noteworthy and are usually not commented on. Contra-standard features, however, will seem shocking, disconcerting, startling, or upsetting.

Applied to the subject at hand, we get another sense of what a fundamental difference it can make to see these works under one banner, rather than another. Relative to the classic category of erotic art, the blunt sexual explicitness of Schiele, Mapplethorpe, or Moore is a contra-standard feature and as such is perceived as shocking and disconcerting. It is the feature that is singled out, time and again, for critical attention and is continually dwelt and commented upon in reviews. Relative to the category of pornography (or pornographic art), however, sexual explicitness would be a standard feature. So, if critics were to see these works within that category, they would no longer feel frustrated or taken aback by that feature or feel the need to devote all their attention to it. Instead, they could focus freely on what Walton has called the 'variable features' of these works, i.e. the features that make a Schiele drawing or a Mapplethorpe photo precisely different from and superior to the average pornographic representation. This seems a more fruitful and more accurate way to approach these works - I say 'more accurate' because for Walton 'the correct way of perceiving a work is likely to be that in which it has a minimum number of contra-standard features for us' (1970: 360).

Finally, the rejection of a strict art-pornography divide is of vital importance not only for a proper critical appreciation of existing artworks but also for the production of future pornographic artworks. Most of pornography, it should be granted, is terribly deficient on aesthetic and artistic grounds (not to mention moral grounds). There are in fact so few exceptions to this general rule that artists may be forgiven in thinking, along with the majority of the public, that art and pornography really are incompatible. Such a thought, that it is not just difficult but simply impossible to make something that is both art and pornography, will obviously prevent anyone with artistic ambition from experimenting in this direction. That is why the outcome of the philosophical debate is not without practical import. If philosophers of art were to conclude that art and pornography are indeed mutually exclusive, this will confirm the wide-spread misconception and help to turn the realm of pornography - already perceived as 'a toxic wasteland, poisonous to the reputation and alive with career pathogens' (Moore 2009: 17) - into a permanent "no-go" zone for artists.

Cementing the (conscious or unconscious) self-censorship of artists in this regard would not be such a bad thing if sex was just a marginal, unimportant aspect of human life. But it clearly is not. Sexual experiences involve the deepest corners of our selves and are among the most intense, powerful, emotional, and profound experiences we have. If 
pornography, which offers the most direct representation of, and access to, such experiences, can in principle be lifted into the realm of art, and this is what I have argued for in this chapter, then I think we have every reason to encourage artists to attempt just that: to make intense, powerful, and profound works of pornographic art and rescue this much-maligned genre from the clutches of the seedy porn-barons.

\section{BIBLIOGRAPHY}

Amis, Kingsley \& Howard, E.J. (1972) 'The Novelist's View.' Pornography: The Longford Report. London: Coronet Books. 150-161.

Bartel, Christopher (2010) 'The Fine Art of Pornography? The Conflict Between Artistic Value and Pornographic Value.' Porn - Philosophy for Everyone: How to Think with Kink. Ed. Dave Monroe. Oxford: Wiley-Blackwell. 153-165.

Berger, Fred (1977) 'Pornography, Sex, and Censorship.' Social Theory and Practice 4: 183209.

Berger, John (1972) Ways of Seeing. London: Penguin.

Blackburn, Simon (2006) Lust. Oxford: Oxford University Press.

Bovens, Luc (1998) 'Moral Luck, Photojournalism, and Pornography.' Journal of Value Inquiry 32: 205-217.

Brown, Curtis (2002) 'Art, Oppression, and the Autonomy of Aesthetics.' Arguing About Art: Contemporary Philosophical Debates. Eds. Alex Neill \& Aaron Ridley. London: Routledge. 399-421.

Brownmiller, Susan (1975) Against Our Will: Men, Women and Rape. New York: Fawcett.

Carroll, Noël (2009) On Criticism. New York: Routledge.

Cembalest, Robin et al. eds. (1989) 'What is Pornography?' Art News, October Issue.

Chaucer, Lynn S (1998) Reconcilable Differences: Confronting Beauty, Pornography, and the Future of Feminism. Berkeley: University of California Press, 1998.

Clark, Kenneth (1956) The Nude: A Study in Ideal Beauty. London: John Murray.

Clarke, John R. (2003) Roman Sex. New York: Harry N. Abrams.

Corliss, Richard (1999) 'In Defense of Dirty Movies.' Time Magazine 5 July.

Danto, Arthur C. (1995) Playing with the Edge: The Photographic Achievement of Robert Mapplethorpe. Berkeley: University of California Press. 
Danto, Arthur C. (2003) The Abuse of Beauty: Aesthetics and the Concept of Art. Chicago: Open Court.

Danto, Arthur C. (2005) Unnatural Wonders. New York: Columbia University Press.

Dwyer, Susan (2008) 'Pornography.' Routledge Companion to Philosophy and Film. Eds.

Paisley Livingston \& Carl Plantinga. London \& New York: Routledge. 515-526.

Eaton, Anne W. (2007) 'A Sensible Anti-Porn Feminism.’ Ethics 117: 674-715.

Elliott, George P. (1970) ‘Against Pornography.' Perspectives on Pornography. Ed. Douglas Hughes. New York: St Martin's Press. 72-95.

Ellis, Havelock (2007) Studies in the Psychology of Sex: Volume 4. Bibliobazaar.

Ellis, John (2006) 'On Pornography,' Pornography. Film and Culture. Ed. P. Lehman. New

Brunswick, Rutgers University Press. 25-47.

Feinberg, Joel (1979) The Idea of the Obscene. Lawrence: University of Kansas Press.

Feinberg, Joel (1985) Offense to Others. Oxford: Oxford University Press.

Freud, Sigmund (1961) Civilization and its Discontents (Standard Edition, Volume 21). London: Hogarth Press and the Institute of Psycho-Analysis.

Gaut, Berys (2007) Art, Emotion and Ethics. Oxford: Oxford University Press.

Gracyk, Theodore (1987) 'Pornography as Representation: Aesthetic Considerations.' The Journal of Aesthetic Education 21.4: 103-121.

Graham, Gordon (2008) 'Sex and Violence in Fact and Fiction.' Media-Ethics. Ed. Matthew Kieran, New York: Routledge. 152-164.

Huer, Jon (1987). Art, Beauty, and Pornography: A Journey Through American Culture. Buffalo: Prometheus.

Irvin, Sherri (2008). 'The Pervasiveness of the Aesthetics in Ordinary Experience.' British Journal of Aesthetics 48: 29-44.

Kipnis, Laura (2006). 'How to Look at Pornography.' Pornography: Film and Culture. Ed.

Peter Lehman. New Brunswick: Rutgers University Press, 118-132.

Kieran, Matthew (2001) 'Pornographic Art.' Philosophy and Literature 25: 31-45.

Kieran, Matthew (2002) 'On Obscenity: The Thrill and Repulsion of the Morally Prohibited.' Philosophy and Phenomenological Research 64: 31-55.

Langton, Rae (1993) 'Speech Acts and Unspeakable Acts.' Philosophy and Public Affairs 22: 305-330.

Lawrence, D.H. (1929) Pornography and Obscenity. London: Faber \& Faber.

Levinson, Jerrold (1998) 'Erotic Art.' The Routledge Encyclopedia of Philosophy. Ed. E. Craig. London: Routledge. 406-9. 
Levinson, Jerrold (2003) 'Sexual Perversity.' The Monist 86.1.

Levinson, Jerrold (2005) 'Erotic Art and Pornographic Pictures.' Philosophy and Literature $29: 228-240$.

Longino, Helen (1980) 'Pornography, Oppression, and Freedom,' Take Back the Night

Women on Pornography. Ed. Laura Lederer, New York: William Morrow, 40-54.

McElroy, Wendy (1995) XXX: A Woman's Right to Pornography. New York: St Martin's Press.

MacKinnon, Catharine (1987). 'Francis Biddle's Sister: Pornography, Civil Rights, and Speech.' Feminism Unmodified: Discourses on Life and Law. Cambridge, MA: Harvard University Press. 163-197.

Maes, Hans (2009) 'Art and Pornography.' Journal of Aesthetic Education 43: 107-116.

Maes, Hans (2011a) 'Art or Porn: Clear Division or False Dilemma?' Philosophy and Literature.

Maes, Hans (2011b) 'Drawing the Line: Art versus Pornography' Philosophy Compass.

Mag Uidhir, Christy (2009) 'Why Pornography Can't Be Art.' Philosophy and Literature 33: 193-203.

Mahon, Alyce (2005) Eroticism \& Art. Oxford: OUP.

Marcus, Steven (1964) The Other Victorians: A Study of Sexuality and Pornography in MidNineteenth-Century England. New York: Basic Books.

Mey, Kerstin (2007) Art \& Obscenity. London: I.B.Tauris.

Moore, Alan (2008) 'Drawings of Harlots.' Erotic Comics: A Graphic History. Ed. Tim Pilcher. Lewis: Ilex.

Moore, Alan (2009) Twenty-five thousand years of erotic freedom. New York: Abrams.

Nabokov, Vladimir (1995) 'On a Book Entitled Lolita.' Lolita. London: Penguin. 311-317.

Nussbaum, Martha C. (1995) 'Objectification.' Philosophy and Public Affairs 24: 249-291.

Nussbaum, Martha C. (2004) Hiding from Humanity: Disgust, Shame and the Law. Princeton: Princeton University Press.

Williams, Bernard ed. (1982) Obscenity and Film Censorship: An Abridgement of the Williams Report. Cambridge: Cambridge University Press.

Plumb, Ali (2011) '15 Amazing Adverts from 15 Amazing Directors' Empire Online: http://www.empireonline.com/features/amazing-adverts-from-amazing-directors/p7.

Pornography: The Longford Report. London: Coronet Books, 1972.

The Puzzy Power Manifesto: Statement on Women and Sensuality. 1997. http://www.innocentpictures.com/constance_en_manifest.htm 
Rea, Michael C. (2001) 'What is Pornography?' Nous 35.1: 118-145,

Russell, Diana E.H. (1998) Dangerous Relationships: Pornography, Misogyny, and Rape. London: Sage.

Schopenhauer, Arthur (1965). The World as Will and Representation. Volume 1. Trans. E.F.J.

Payne. New York: Dover.

Scruton, Roger (1986) Sexual Desire, New York: The Free Press.

Scruton, Roger (2003) 'The Moral Birds and Bees,' National Review, 15 September.

http://www.nationalreview.com/flashback/flashback200602140942.asp Accessed 14 October 2007.

Scruton, Roger (2005) 'Flesh from the Butcher: How to Distinguish Eroticism from Pornography.' Times Literary Supplement 15 Apr. 2005, 11-13.

Scruton, Roger (2009) Beauty. Oxford: Oxford University Press.

Shaftesbury, Third Earl of (1999), Characteristics of Men, Manners, Opinions, Times. Ed.

Lawrence Klein, Cambridge: Cambridge University Press.

Shusterman, Richard (2007) 'Asian Ars Erotica and the Question of Sexual Aesthetics' Journal of Aesthetics and Art Criticism 65. 55-68.

Shusterman, Richard (2008) 'Aesthetic Experience: From Analysis to Eros.' Aesthetic Experience. Eds. Richard Shusterman \& Adele Tomlin. London: Routledge , 79-97.

Slade, Joseph W (2001) Pornography and Sexual Representation: A Reference Guide. Westport: Greenwood Press.

Sontag, Susan (1994) 'The Pornographic Imagination.' Styles of Radical Will. London: Vintage, 35-73.

Steinem, Gloria (1995) 'Erotica and Pornography: A Clear and Present Difference.' The Problem of Pornography. Ed. Susan Dwyer. Belmont: Wadsworth. 29-33.

Steiner, George (1975) 'Night Words: High Pornography and Human Privacy.' The Pornography Controversy. Ed. Ray C. Rist. New Brunswick: Transaction Books. 203216.

Talvacchia, Bette (1999) Taking Positions: On the Erotic in Renaissance Culture. Princeton: Princeton University Press.

Wallace, Marina, Martin Kemp and Joanne Bernstein (2007) Seduced: Art \& Sex from Antiquity to Now. London: Merrel.

Walton, Kendall (1970) 'Categories of Art.' Philosophical Review 79. 334-367.

Waugh, Thomas (1995) 'Men's Pornography: Gay vs Straight,' The Problem of Pornography. Ed. Susan Dwyer. Belmont: Wadsworth. 142-161. 
Webb, Peter (1975) The Erotic Arts. London: Secker \& Warburg.

Williams, Linda (1989) Hard-Core: Power, Pleasure, and the "Frenzy of the Visible." Berkeley, University of California Press.

Williams, Linda ed. (2004) Porn Studies. Durham: Duke University Press.

Williams, Linda (2008) Screening Sex. Durham: Duke University Press.

Willis, Ellen (1995) 'Feminism, Moralism, and Pornography.' The Problem of Pornography. Ed. Susan Dwyer. Belmont: Wadsworth. 170-176. 